\title{
Moderate tidal volumes and oxygen exposure during initiation of ventilation in preterm fetal sheep
}

\author{
Noah H. Hillman' ${ }^{1}$ Timothy J. Moss², llias Nitsos ${ }^{2}$ and Alan H. Jobe ${ }^{1,2}$
}

BACKGROUND: Preterm infants often receive mechanical ventilation and oxygen at birth. Exposure to large tidal volumes $\left(V_{T} s\right)$ at birth causes lung inflammation, and oxygen may amplify the injury. We hypothesized that normal $V_{T}$ ventilation at birth causes lung injury that is exacerbated by $95 \%$ oxygen. METHODS: The head and chest of anesthetized preterm fetal sheep (129 $\pm 1 \mathrm{~d}$ gestation) were surgically exteriorized while maintaining the placental circulation. Fetuses were randomized to four groups with either $V_{T}$ ventilation to $6 \mathrm{ml} / \mathrm{kg}$ or continuous positive airway pressure of $5 \mathrm{~cm} \mathrm{H}_{2} \mathrm{O}$, and either $95 \% \mathrm{O}_{2} / 5 \% \mathrm{CO}_{2}$ or $95 \% \mathrm{~N}_{2} / 5 \% \mathrm{CO}_{2}$. Age-matched fetuses were used as controls. After a 15 -min intervention, the fetal lamb was returned to the uterus for $1 \mathrm{~h} 45 \mathrm{~min}$.

RESULTS: In ventilated lambs, $V_{T}$ was $6.2 \pm 0.4 \mathrm{ml} / \mathrm{kg}$ at $15 \mathrm{~min}$. Ventilation increased proinflammatory cytokines as compared with controls and lambs on continuous positive airway pressure, with recruitment of primarily monocytes to bronchoalveolar lavage fluid. Early response protein 1 was activated around the bronchioles in $V_{\mathrm{T}}$-ventilated animals. The 15-min oxygen exposure did not change inflammatory mediators or other markers of lung and oxidative stress.

CONCLUSION: A $V_{T}$ of $6-7 \mathrm{ml} / \mathrm{kg}$ at birth increased early markers of injury and lung inflammation. Brief exposure to $95 \%$ oxygen did not alter lung inflammation.

$\mathbf{T}$ The initiation of ventilation at birth is unique because the fetal lung must rapidly transition from fluid-filled airspaces to gas exchange to sustain life (1). Approximately $10 \%$ of newborns need some assistance with this transition, and the majority of preterm infants $\leq 1,500 \mathrm{~g}$ receive some assisted ventilation $(2,3)$. Many preterm infants are exposed to positive-pressure ventilation with large tidal volumes $\left(V_{\mathrm{T}} \mathrm{s}\right)$ and oxygen, and this can cause airway epithelial injury and lung inflammation (4-6). Recent clinical studies of resuscitation demonstrate that clinicians are not able to regulate positive end expiratory pressure (PEEP), peak inspiratory pressures, or $V_{\mathrm{T}}$ given to infants (or in simulation) reliably, and the delivery of high $V_{\mathrm{T}}$ is frequent $(6,7)$. The initiation of ventilation in preterm sheep with escalating $V_{\mathrm{T}}$ to $15 \mathrm{ml} / \mathrm{kg}$ stretches the airways and causes airway epithelial injury and diffuse lung inflammation (8-10). Large $V_{\mathrm{T}}$ ventilation at birth also permits plasma and interstitial proteins to move into airspace, which decreases the response to subsequent surfactant treatment (11). The path to bronchopulmonary dysplasia may begin with the initiation of ventilation because large $V_{\mathrm{T}}$ at birth increases acute-phase response genes involved in inflammation, angiogenesis, vascular remodeling, and apoptosis within the lung (10). It is hypothesized that lower $V_{\mathrm{T}}$ during resuscitation, similar to the normal $V_{\mathrm{T}}$ of $5 \mathrm{ml} / \mathrm{kg}$ of spontaneously breathing infants, would cause less injury.

The 2010 International Liaison Committee on Resuscitation guidelines recommend that term infants be resuscitated with room air instead of oxygen (2) given that resuscitation with $100 \%$ oxygen can delay the first spontaneous breath and may increase mortality as compared with room air resuscitation (12). Unfortunately, preterm infants often do not respond to resuscitation with room air, with the majority of preterm infants requiring oxygen concentrations of about $40 \%$ to maintain appropriate oxyhemoglobin saturations and heart rates during the first minutes of life $(13,14)$. Extremely preterm infants resuscitated with $90 \%$ oxygen had increased markers of oxidative stress, inflammation, and risk of bronchopulmonary dysplasia as compared with infants resuscitated with $30 \%$ oxygen (15). Exposure to high oxygen concentrations may also have a direct effect on the gene expression patterns within the epithelial cells (16). It is still unclear if a brief exposure to oxygen during resuscitation can contribute to lung inflammation and alter gene expression in preterm infants.

Because it is difficult to isolate the individual components of resuscitation from subsequent ventilation at birth, we have used a premature fetal sheep model to maintain placental support during ventilation to allow time for markers of injury to develop $(8,10)$. Although we previously used an escalating $V_{\mathrm{T}}$ to $15 \mathrm{ml} / \mathrm{kg}$ for $15 \mathrm{~min}$ to cause lung injury, Brew et al. recently demonstrated modest anatomic injury at $24 \mathrm{~h}$ following $2-\mathrm{h} V_{\mathrm{T}}$ ventilation to $5 \mathrm{ml} / \mathrm{kg}$ with repair by $15 \mathrm{~d}$ (17). To test the hypothesis that initiation of ventilation with a lower $V_{\mathrm{T}}$ would not injure the preterm lung, we have evaluated a $V_{\mathrm{T}}$ below the normal $V_{\mathrm{T}}$ of $8 \mathrm{ml} / \mathrm{kg}$ of spontaneously breathing preterm lambs on continuous positive airway pressure (18). We asked if the lower $V_{\mathrm{T}}$ caused activation of acute-phase responses and inflammation. In addition, we tested whether exposure to $95 \%$ oxygen for $15 \mathrm{~min}$ changed lung inflammation and markers of oxidative stress. 


\section{RESULTS}

All lambs ( $n=5-6 /$ group) survived the fetal interventions and in utero recovery, and there were no differences in the venous blood gas values between ventilation groups before or after the intervention (Table 1). The target $V_{\mathrm{T}}$ of $6-7 \mathrm{ml} / \mathrm{kg}$ was achieved in the ventilated groups by $6 \mathrm{~min}(6.0 \pm 0.1 \mathrm{ml} / \mathrm{kg})$ but required the maximal peak inspiratory pressure of $40 \mathrm{~cm} \mathrm{H}_{2} \mathrm{O}$ in all animals. The average $V_{\mathrm{T}}$ remained stable by $15 \mathrm{~min}$ at $6.2 \pm 0.2 \mathrm{ml} /$ $\mathrm{kg}$. Total protein levels from the bronchoalveolar lavage fluid (BALF) were low $(19 \pm 2 \mathrm{mg} / \mathrm{kg})$ and similar among all ventilation groups and control animals. Injury scoring of hematoxylin and eosin-stained tissues demonstrated minimal epithelial sloughing, hemorrhage, and inflammatory cells for all groups with no difference between groups (Table 1). Thus, the $V_{\mathrm{T}}$ of $6.2 \mathrm{ml} / \mathrm{kg}$ or the oxygen did not cause microscopic injury.

\section{Lung Inflammation}

Ventilation for $15 \mathrm{~min}$ increased mRNA for the proinflammatory cytokines (interleukin (IL)-1 $\beta$, IL-6, IL-8, monocyte chemotactic protein (MCP)-1, and MCP-2) in the lung tissue (Figure 1). Oxygen exposure did not increase these cytokines. Exposure to a PEEP of $5 \mathrm{~cm} \mathrm{H}_{2} \mathrm{O}$ with or without $100 \%$ oxygen did not increase cytokine mRNA as compared with controls. mRNA values for IL- $1 \beta$, IL-8, and IL- 6 in epithelium from the trachea did not change with ventilation or oxygen exposure (data not shown). MCP-1 protein was detected in the

Table 1. Birth weights, $V_{T^{\prime}}$ venous blood gases, and injury scores

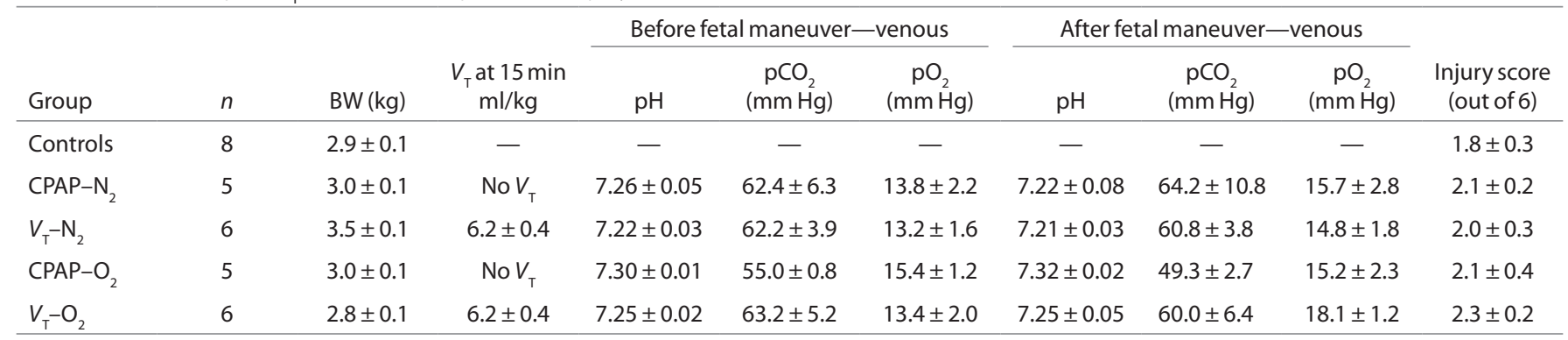

$B$ W, birth weight; $C P A P$, continuous positive airway pressure; $V_{T}$, tidal volume.
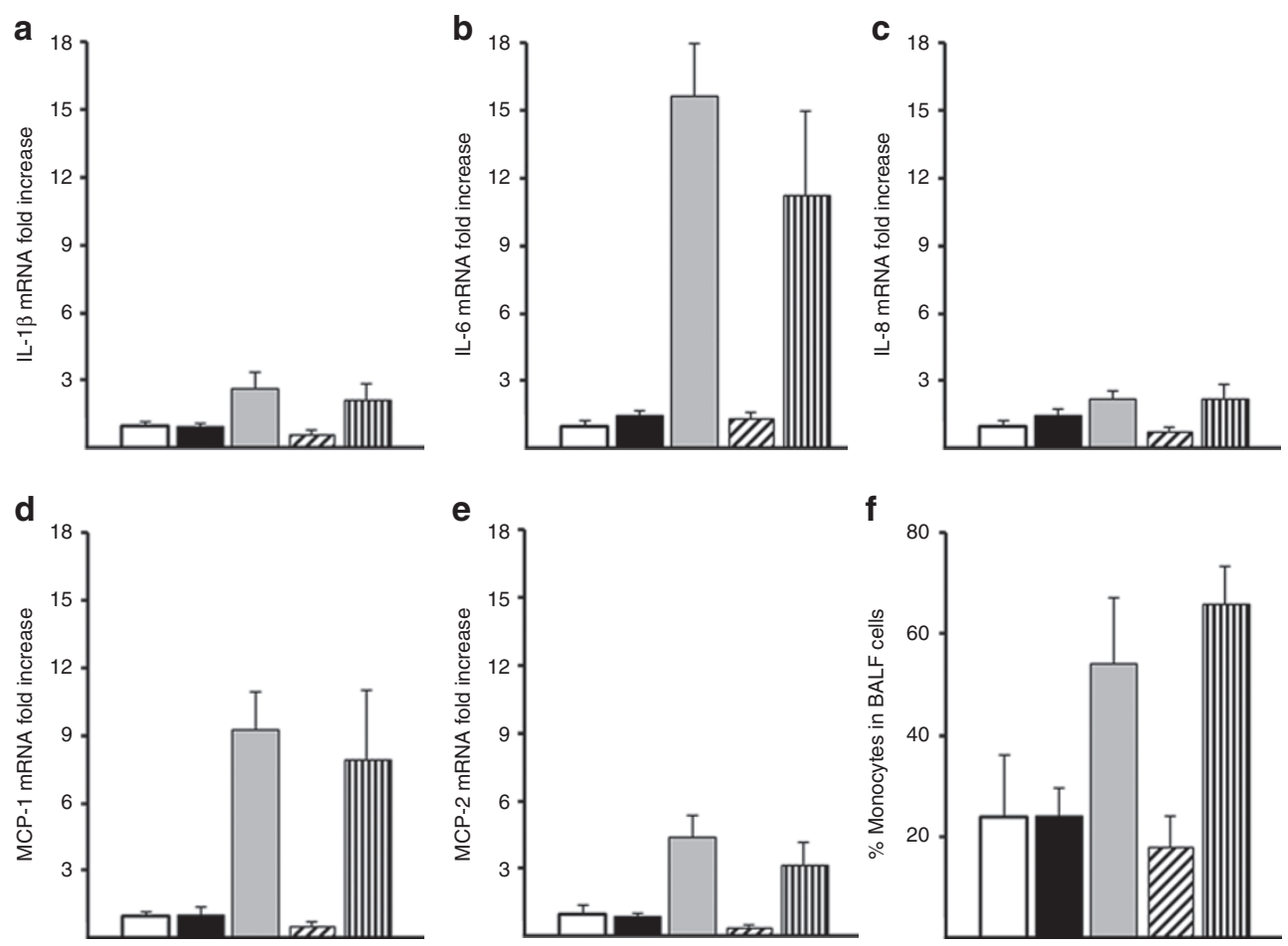

Figure 1. Tidal volume $\left(V_{T}\right)$ ventilation increased mRNA for proinflammatory cytokines. (a) Interleukin (IL)-1 $\beta$, (b) IL-6, (c) IL-8, (d) monocyte chemotactic protein-1 (MCP-1), and (e) MCP-2 mRNA increased with mechanical ventilation $\left(V_{T}\right)(P<0.05$ vs. controls and lambs receiving only continuous positive airway pressure (CPAP)). There were no additional effects of oxygen $\left(\mathrm{O}_{2}\right)$ (vertical striped bar) on the increased mRNA from mechanical ventilation with nitrogen $\left(\mathrm{N}_{2}\right.$ ) (gray bars). Animals receiving only CPAP of $5 \mathrm{~cm} \mathrm{H}_{2} \mathrm{O}$, with $\mathrm{N}_{2}$ (black bars) or $\mathrm{O}_{2}$ (dashed bars) did not have increased cytokine mRNA. The mRNA was measured from complementary DNA using RT-PCR and reported as fold increase over the mean of controls. (f) Monocytes in BALF, reported as percentage of total cells, increased in lambs receiving mechanical ventilation $(P<0.05$ vs. controls and lambs receiving only CPAP). White column, controls; black column, CPAP nitrogen; gray column, $V_{\mathrm{T}}$ nitrogen; diagonal stripes, CPAP oxygen; vertical stripes, $V_{\mathrm{T}}$ oxygen. BALF, bronchoalveolar lavage fluid. 
cytoplasm of peripheral lung tissue cells in animals receiving $V_{\mathrm{T}}$ ventilation (data not shown). Inflammatory cells increased in the BALF of lambs receiving mechanical ventilation, with an overall increase in the percentage of monocytes (Figure 1). As compared with the other cytokines, the induction of IL- 8 was modest (two- to threefold), and the neutrophil recruitment to the BALF was surprisingly low and occurred in lambs with the higher IL- 8 mRNA values. Although occasional CD3 ${ }^{+}$ cells were present in the lung tissue, there was no increase in recruitment of these $T$ cells to the lung with ventilation or oxygen exposure.

\section{Acute-Phase Response Genes}

Early growth response protein 1 (Egr-1) activation in control lambs and lambs receiving a PEEP of $5 \mathrm{~cm} \mathrm{H}_{2} \mathrm{O}$ was limited to occasional staining within the blood vessels (Figure $2 \mathbf{a}, \mathbf{e}, \mathbf{f}, \mathbf{h}$ ). Egr-1 increased in the cells surrounding the smaller airways and the connective tissue with mechanical ventilation (Figure 2c,d) as compared with controls (Figure 2a,b), and the pattern of increased expression was not altered by exposure to oxygen (Figure $2 \mathrm{e}-\mathbf{i}$ ). Blinded scoring confirmed increased Egr-1 protein in airways and connective tissue with mechanical ventilation (Table 2). There was little to no Egr-1 activation within the distal lung parenchyma (staining score: $0.13 \pm 0.04$ ) (Figure $2 \mathrm{c}$ ). Although the Egr-1 protein is abundantly present at $2 \mathrm{~h}$ after intervention, the mRNA levels of transcription factors downstream of Egr-1 (platelet-derived growth factor A, fibroblast growth factor 2, arachidonate 5-lipoxygenase, epithelial growth factor receptor) were not altered by ventilation; similar effects were found in the case of mRNA for the counter-regulatory protein (NGFI-A binding protein 2) (Table 2). HSP70 mRNA was localized to the bronchial epithelium of surgical controls and fetal lambs receiving only PEEP but was lost from the epithelium of lambs receiving mechanical ventilation. HSP70 mRNA was not increased in the airway smooth muscle in lambs receiving ventilation with a $V_{\mathrm{T}}$ of $6 \mathrm{ml} / \mathrm{kg}$. Heme oxygenase 1 (HO-1) mRNA from lung tissue did not change in these lambs as compared with that of the surgical controls (Table 3). HO-1 protein was localized within the cytoplasm of occasional cells within the distal parenchyma, but the distribution and number of cells did not change between intervention groups.

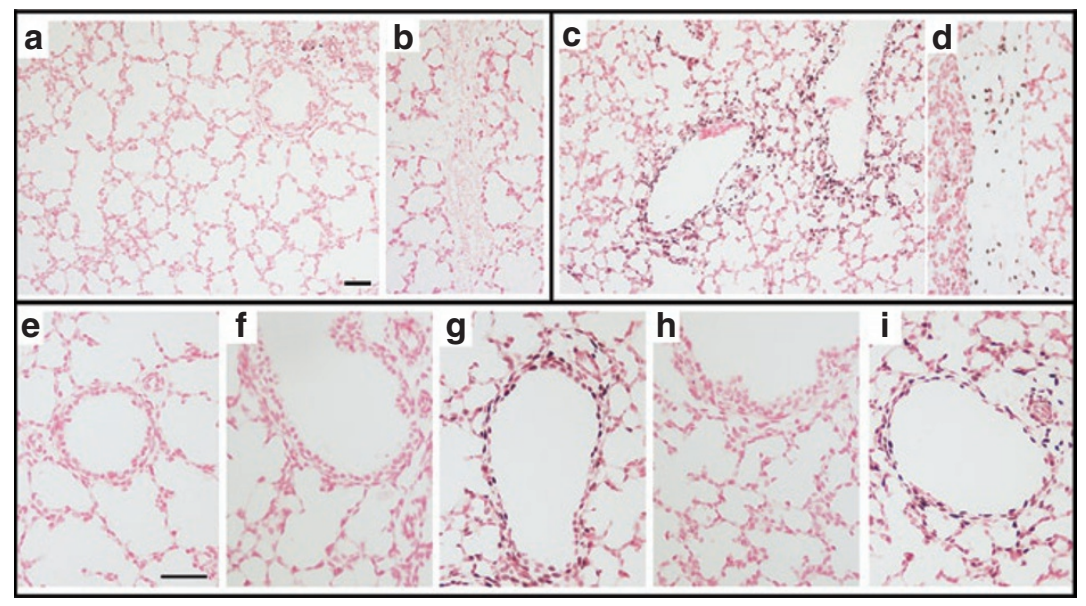

Figure 2. Early response protein-1 (Egr-1) protein increased around bronchioles with mechanical ventilation. (a,b,e) Control lambs had only occasional Egr-1 staining in the (a) vessels and none was found in (b) intralobar connective tissue (20x original magnification). (c-d) Egr-1 signal increased with mechanical ventilation with nitrogen $\left(\mathrm{N}_{2}\right)$ and was localized to (c) cells around bronchioles and (d) in cells within connective tissue (20x original magnification). There was minimal staining in the distal epithelium. (e-i) Higher-power images of Egr-1 staining. Lambs receiving $V_{\mathrm{T}}$ ventilation with (g) $\mathrm{N}_{2}$ and (i) $\mathrm{O}_{2}$ demonstrate increased Egr-1 surrounding small airways. Continuous positive airway pressure exposure, with (f) $\mathrm{N}_{2}$ or (h) $\mathrm{O}_{2}$ did not increase staining. Scale bar $=50 \mu \mathrm{m}$.

Table 2. Egr-1 protein expression and mRNA for Egr-1-responsive transcription factors

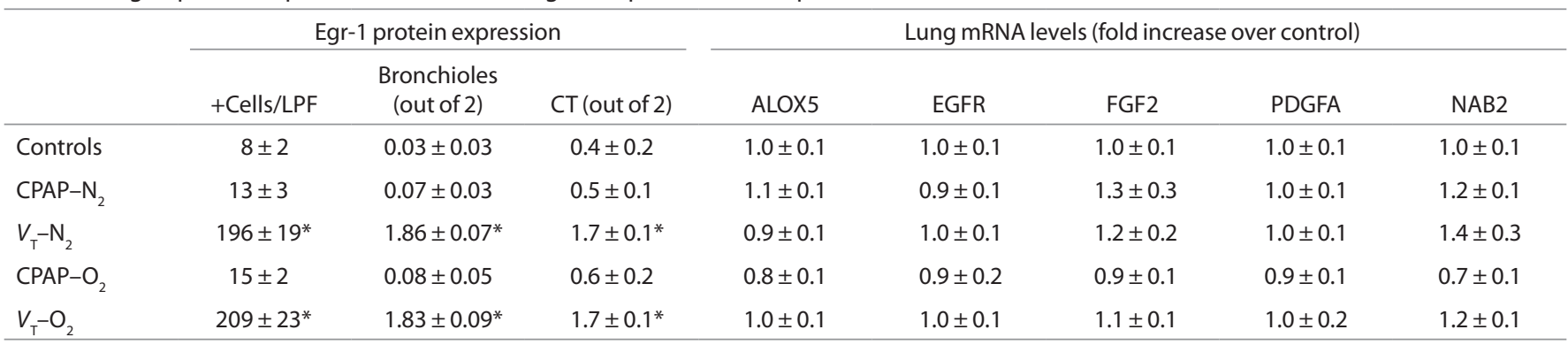

ALOX5, arachidonate 5-lipoxygenase; CPAP, continuous positive airway pressure; CT, connective tissue; EGFR, epithelial growth factor receptor; Egr-1, early response protein-1; FGF2, fibroblast growth factor 2; LPF, low-power field; NAB2, NGFI-A binding protein 2; PDGFA, platelet-derived growth factor A; $V_{T}$, tidal volumes.

${ }^{*} P<0.05$ vs. control and CPAP animals. 
Table 3. Heme-oxidase 1 and superoxide dismutase 1 in lung

\begin{tabular}{lccccc}
\hline & \multicolumn{3}{c}{ Lung tissue } & & BALF \\
\cline { 2 - 4 } & $\begin{array}{c}\text { HO-1 mRNA } \\
\text { (fold increase) }\end{array}$ & $\begin{array}{c}\text { HO-1 protein } \\
\text { (cells/LPF) }\end{array}$ & $\begin{array}{c}\text { SOD1 mRNA } \\
\text { (fold increase) }\end{array}$ & $\begin{array}{c}\text { SOD activity } \\
(\mathrm{U} / \mathrm{ml})\end{array}$ \\
\hline Controls & $1.0 \pm 0.12$ & $28 \pm 6$ & $1.0 \pm 0.19$ & & $0.19 \pm 0.05$ \\
$\mathrm{CPAP} \mathrm{N}_{2}$ & $1.0 \pm 0.06$ & $50 \pm 11$ & $1.0 \pm 0.08$ & & $0.31 \pm 0.07$ \\
$V_{\mathrm{T}}-\mathrm{N}_{2}$ & $0.8 \pm 0.10$ & $59 \pm 15$ & $0.9 \pm 0.04$ & & $0.22 \pm 0.01$ \\
$\mathrm{CPAP} \mathrm{O}_{2}$ & $0.9 \pm 0.02$ & $55 \pm 10$ & $0.8 \pm 0.04$ & & $0.10 \pm 0.04$ \\
$V_{\mathrm{T}}-\mathrm{O}_{2}$ & $1.0 \pm 0.03$ & $42 \pm 11$ & $0.9 \pm 0.05$ & & $0.39 \pm 0.08$
\end{tabular}

BALF, bronchoalveolar lavage fluid; CPAP, continuous positive airway pressure; $\mathrm{HO}-1$, heme oxygenase $1 ;$ LPF, low-power field; SOD1, superoxide dismutase $1 ; V_{\text {T, }}$ tidal volume.

\section{Oxidative Response}

There were no differences in the inflammatory and acutephase responses when lambs were exposed to 95\% oxygen for the resuscitation. Superoxide dismutase 1 (SOD1) mRNA from peripheral lung tissue did not change in any of the groups as compared with that of the surgical controls (Table 3). Total SOD activity also did not change in the BALF. Hifl $\alpha$ and Hif $2 \alpha$ proteins are expressed in the fetal lung at $129 \mathrm{~d}$ in control animals, with staining in the epithelial cells surrounding the bronchioles and in cells with a distribution similar to type II cells. There was no difference in the expression pattern for Hifla and Hif2 $\alpha$ between intervention groups, with or without oxygen, and control animals. Arginase 1 protein also did not change in the epithelium or lung parenchyma with either ventilation or oxygen exposure.

\section{DISCUSSION}

We found that, similar to large $V_{\mathrm{T}}$ ventilation, ventilation with a $V_{\mathrm{T}}$ of $6.2 \mathrm{ml} / \mathrm{kg}$ for $15 \mathrm{~min}$ caused increased expression of acute-phase response genes and lung inflammation that are localized primarily around the bronchioles. The low overall release of total protein into the BALF and lack of airway epithelial sloughing indicated less damage than previously reported for a higher $V_{\mathrm{T}}$ of $15 \mathrm{ml} / \mathrm{kg}(5,8)$. We did not find additional inflammation or markers of oxidative stress when lambs were ventilated for $15 \mathrm{~min}$ with $95 \%$ oxygen instead of nitrogen.

Ventilation of the preterm lungs with normal $V_{\mathrm{T}}$ at birth caused lung inflammation and monocyte recruitment to the bronchoalveolar space, which may have been a response to the cytokines MCP-1, MCP-2, and IL-6. Our previous fetal sheep experiments with larger $V_{\mathrm{T}} \mathrm{s}$ demonstrated increased mRNA for IL-1 $\beta$, MCP-1, IL-8, and IL- 6 at 45 min after injury, whereas by $3 \mathrm{~h}$ after injury the IL- 6 and IL- 8 mRNA levels had begun to fall and these returned to baseline by $24 \mathrm{~h}(8-10)$. In this study, we did not find an additive effect of oxygen on proinflammatory cytokines. We previously found a small, twofold increase in lung IL- $1 \beta$ mRNA with $100 \%$ oxygen use in near-term lambs (140 d gestational age) ventilated with a $V_{\mathrm{T}}$ of $9 \mathrm{ml} / \mathrm{kg}$ for $3 \mathrm{~h}$ as compared with lambs ventilated with $21 \%$ oxygen, but IL- 6 and IL- 8 did not change with oxygen in those lambs (4). The addition of $100 \%$ oxygen for $30 \mathrm{~min}$ to newborn rats ventilated with large $V_{\mathrm{T}} \mathrm{s}$ of 25 or $40 \mathrm{ml} / \mathrm{kg}$ caused moderate and inconsistent changes in the mRNA expression of proinflammatory cytokines (19). Newborn rats exposed to low $V_{\mathrm{T}}$ ventilation $(3.5 \mathrm{ml} / \mathrm{kg})$ for $8 \mathrm{~h}$ had increased mRNA for IL-6 and CXCL-2 (homolog to IL-8), but IL-1 $\beta$ did not change (20). The addition of $50 \%$ oxygen to low $V_{\mathrm{T}}$ ventilation caused a modest increase in the IL-6 and CXCL-2 mRNA levels (20). Due to their consistent increases with ventilation, IL-6 or MCP-1 may be appropriate targets for pharmacologic interventions. However, it should be noted that our previous attempts to inhibit inflammation at birth with corticosteroids or specific cytokine inhibitors have been unsuccessful $(21,22)$. Our data demonstrate that inflammation is activated by low $V_{\mathrm{T}}$ ventilation at birth and may be inevitable in the setting of positive-pressure ventilation.

Ventilation at birth with a low $V_{\mathrm{T}}$ caused the activation of Egr-1, an acute-phase gene responsive to mechanical stretch (23). Egr-1 is multifunctional and can activate genes ranging from growth factors to coagulation cascades (24). Egr-1 plays an important role in the initiation of inflammation and mice deficient in Egr-1 are more resistant to ventilator-induced lung injury (25). The Egr-1 signal was intense surrounding the bronchioles and in the connective tissue, suggesting airway stretch. Unlike with larger $V_{\mathrm{T}}$ ventilation or ventilation of newborn lambs after birth, there was little Egr-1 activation in the peripheral lung tissue, suggesting lung injury was limited to the airways $(5,21)$. Egr-1 can be activated by hyperoxia, but we did not find activation in lambs receiving only oxygen without $V_{\mathrm{T}}$ ventilation (26). Although the Egr-1 protein showed nuclear staining, there were surprisingly no changes in the mRNA for downstream targets of Egr-1 protein (platelet-derived growth factor A, fibroblast growth factor 2, arachidonate 5-lipoxygenase, and epithelial growth factor receptor). We also did not find changes in the mRNA for NGFI-A binding protein 2, the major counterregulatory protein for Egr-1 (24). The lack of these responses could be due to the timing of the intervention or it could also result from the overall immaturity of the fetal lung. We also did not find differences in HO-1, which responds like many acutephase response elements and is inducible by a variety of stimuli from lipopolysaccharide to hyperoxia (27). We did, however, find a loss of HSP70 mRNA in the epithelium, similar to our previous findings with larger $V_{\mathrm{T}}$ ventilation, giving additional support to airway stretch during initiation with normal $V_{\mathrm{T}}(5)$.

The antioxidant enzymes normally increase two- to threefold in the final $10-15 \%$ of gestation in many species and parallels the development of the surfactant system (28). Lambs born at $129 \mathrm{~d}$ gestational age are just beginning lung maturation and surfactant production. Fetal sheep at $125 \mathrm{~d}$ gestational age can generate a modest increase in some markers of oxidative stress (protein carbonyls and myeloperoxidase activity) following exposure to $7 \mathrm{~d}$ of intra-amniotic lipopolysaccharide (29). Given that the inflammatory system is immature in preterm lambs, the lambs may not have generated a large response to the oxidative stress (30). Although we only measured jugular $\mathrm{PvO}_{2}$ levels at the end of resuscitation, the lack of any increase would suggest maintenance of fetal circulation and shunting across the patent ductus arteriosus, thus limiting any systemic increase in $\mathrm{PaO}_{2}$.

The majority of animal models showing oxidative stress responses from resuscitation use acute hypoxia before ventilation with oxygen or room air (31). The lack of increased 
oxidative responses in our study may result from the lack of preceding hypoxia/hypoperfusion. Resuscitation of newborn piglets with $100 \%$ oxygen after acute hypoxia increased MMP-2 activity in the brain as compared with resuscitation with $21 \%$ oxygen, but animals exposed to $30 \mathrm{~min}$ of $100 \%$ oxygen without previous hypoxia did not demonstrate these changes (32). Similar to our findings on SOD, there were no differences found in antioxidant enzymes (SOD, catalase, or glutathione peroxidase) between term lambs ventilated with oxygen and air (33).

We did not find changes in oxygen-sensitive proteins (Hifla, Hif $2 \alpha$, or arginase 1) with a brief oxygen exposure. Hif1 $\alpha$ and Hif $2 \alpha$ are expressed in fetal pulmonary epithelial, smooth muscle, and endothelial cells (34), and help regulate the expression of vascular endothelial growth factor. Prolonged ventilation of premature baboons leads to decreased Hifla expression (35). Ventilation of surfactant-deficient very preterm lambs (gestational age $115 \mathrm{~d}$ ) for $4 \mathrm{~h}$ with high oxygen concentrations decreased Hif1 $\alpha$ and Hif2 $\alpha$ protein and decreased vascular endothelial growth factor mRNA (36). Although in our study Hifl $\alpha$ and Hif $2 \alpha$ were present in the fetal lung, we did not find consistent decreases with this brief period of normal ventilation or with the addition of oxygen. We previously have not seen differences in vascular endothelial growth factor mRNA or vascular endothelial growth factor receptor protein in lambs exposed to short periods of ventilation (5). Arginase 1 competes with nitric oxide synthase for L-arginine, and activation impairs airway muscle relaxation. In newborn rat pups exposed to $50 \%$ oxygen for $7 \mathrm{~d}$, arginase 1 is increased in the airway epithelium (37). Short-term exposure to $95 \%$ oxygen during fetal ventilation did not affect arginase 1 expression. The lack of changes in markers of oxidative stress and oxygen-sensitive proteins suggests that short-term exposure of preterm infants to oxygen may not increase injury caused by ventilation.

There are several limitations of the study that should be noted. As with many large-animal studies, the number of animals per group was only five-six, so small differences between groups will not be detected. Although our focus was on the evaluations of inflammation, acute-phase genes, and some oxidative markers, other genes may have changed within the model. This fetal sheep model, which maintains placental blood flow and ductal shunting, may have limited the systemic effects of oxygen on the lungs, as the $\mathrm{PvO}_{2}$ did not change. We used $5 \% \mathrm{CO}_{2}$ in these animals to maintain mild hypercapnia, and our $\mathrm{PvCO}_{2}$ at end of 15 -min ventilation ( $56 \pm 4 \mathrm{~mm} \mathrm{Hg}$ ) was similar to the initial $\mathrm{PvCO}_{2}(58 \pm 3 \mathrm{~mm} \mathrm{Hg})$. The exposure time of $15 \mathrm{~min}$ may also not have been long enough to cause direct oxidant injury to the epithelial cells. We used high peak inspiratory pressures of $40 \mathrm{~cm} \mathrm{H}_{2} \mathrm{O}$ and no PEEP to generate a $V_{\mathrm{T}}$ of only $6-7 \mathrm{ml} / \mathrm{kg}$. We recently demonstrated that PEEP use during resuscitation with high $V_{\mathrm{T}}$ decreases proinflammatory cytokines twofold (9). PEEP use with normal $V_{\mathrm{T}}$ at birth might lessen, but not abolish, the negative effects of ventilation.

\section{Conclusion}

Ventilation of the preterm lung at birth with low $V_{\mathrm{T}}$ leads to airway stretch and lung inflammation. The degree of lung injury is less than what is seen with higher $V_{\mathrm{T}}$ ventilation $(15 \mathrm{ml} / \mathrm{kg})$, and there is minimal protein leak and airway epithelial disruption. In these lambs, oxygen exposure did not alter the inflammatory response to ventilation. Our results support the avoidance of positive-pressure ventilation, even low $V_{\mathrm{T}}$, when possible in preterm infants at birth. Although clinicians should attempt to limit oxygen exposure when possible, the use of supplemental oxygen as needed in preterm infants at birth (2) is supported by a lack of short-term effects of oxygen.

\section{METHODS}

The investigations were approved by the animal ethics committees of the Western Australian Department of Agriculture and Cincinnati Children's Hospital Medical Center.

\section{Maternal Anesthesia and Surgery}

Date-mated Merino ewes with singletons or twins at $129 \pm 1 \mathrm{~d}$ gestation (early alveolarization stage, term is $150 \mathrm{~d}$ in sheep) received ketamine $(5 \mathrm{mg} / \mathrm{kg})$ i.m. and xylazine $(0.5 \mathrm{mg} / \mathrm{kg})$ i.m. for induction of general anesthesia before halothane (1-2\%) anesthesia. Using aseptic techniques, a midline hysterotomy was performed. The head and chest of the preterm lamb were exposed, and the lamb was given $10 \mathrm{mg} / \mathrm{kg}$ ketamine i.m.

\section{Fetal Ventilation Procedure}

The fetal lamb was intubated with a cuffed tube and fetal lung fluid was removed with a catheter using gentle suction (8). Each lamb was randomly assigned to four groups ( $n=5-6 /$ group) based on the type of ventilation and the inspired gas mixture. Lambs received either mechanical ventilation for $15 \mathrm{~min}$ with a rate $30 \mathrm{breaths} / \mathrm{min}$, inspiratory time 1 s, PEEP $0 \mathrm{~cm} \mathrm{H}_{2} \mathrm{O}$ (Bourns BP200 time-cycled, pressure-limited infant ventilator with 12 1/min flow, Bear Medical Systems, Riverside, CA) or continuous positive airway pressure of $5 \mathrm{~cm} \mathrm{H_{2 }} O$ with no $V_{\mathrm{T}}$ (under these conditions the fetal lambs do not breathe spontaneously). Our target $V_{\mathrm{T}}$ was $6-7 \mathrm{ml} / \mathrm{kg}$ with a maximal peak inspiratory pressure limited to $40 \mathrm{~cm} \mathrm{H}_{2} \mathrm{O}$. An in-line flow sensor (Florian Infant Graphics Monitor, Acutronic Medical Systems, Hirzel, Switzerland) was used to continuously measure $V_{\mathrm{T}}$ and pressures. Lambs were further randomized to one of two heated, humidified gases: oxygen, $95 \% \mathrm{O}_{2} / 5 \% \mathrm{CO}_{2}$ or nitrogen, $95 \% \mathrm{~N}_{2} / 5 \% \mathrm{CO}_{2}$. After the 15 -min intervention, the fetus was returned to the uterus, the uterus and maternal abdomen were closed, and the ewe recovered from general anesthesia. Two hours after the intervention, the ewe was humanely killed, followed by immediate surgical delivery of the fetus, which was euthanized with pentobarbital ( $100 \mathrm{mg} / \mathrm{kg}$ i.v.). Jugular venous blood gases were measured before the ventilation intervention and after the intervention. Cord blood gases were measured at delivery.

\section{Lung Processing and BALF Analysis}

At autopsy, a deflation pressure-volume curve was measured after air inflation to $40 \mathrm{~cm} \mathrm{H}_{2} \mathrm{O}$ pressure (38). BALF of the left lung was collected by repetitive saline lavage. BALF was used for measurement of total protein and differential cell counts (39). Total SOD activity was measured in BALF with a colorimetric activity assay (Arbor Assays, Ann Arbor, MI). Tissues from the right lower lung and tracheal epithelial scrapings were snap frozen. The right upper lobe was inflation fixed with $10 \%$ formalin at $30 \mathrm{~cm} \mathrm{H}_{2} \mathrm{O}$ and then paraffin embedded (40).

\section{Quantitative RT-PCR}

mRNA was extracted from tissue from the right lung and trachea (5). ComplimentaryDNA was made using Verso cDNA kit(Thermoscientific, Walthram, MA). Custom Taqman gene primers (Applied Biosystems, Carlsbad, CA) were designed from ovine sequences for arachidonate 5-lipoxygenase, Egr-1, epithelial growth factor receptor, fibroblast growth factor 2 , HO-1, IL-1 $\beta$, IL-6, IL-8, MCP-1, MCP-2, NGFI-A binding protein 2, platelet-derived growth factor $\mathrm{A}$, and superoxide dismutase 1. Quantitative RT-PCR was performed on a 7,300 RT-PCR machine and software (Applied Biosystems). 18S primers were used for 
internal loading control, and results are reported relative to the mean for control animals.

\section{Immunohistochemistry/In Situ Hybridization}

Immunostaining protocols used $5 \mu \mathrm{m}$ paraffin sections of formalin-fixed tissues (8). Primary antibodies included antihuman early response protein 1 (Santa Cruz Biotechnology, Santa Cruz, CA, 1:250), Hifla (internal, 1:500), Hif2a (internal, 1:1,000), CD3 (Dakocytomation, Glostrup, Denmark, 1:100), or argniase 1 (Abcam, Cambridge, MA, 1:150). In situ localization of mRNA was performed with digoxigenin-labeled antisense and sense sheep riboprobes for HSP70 (Roche, Indianapolis, IN) (5). Random, blinded hematoxylin and eosin-stained sections $(\times 10 /$ slide) were scored (0-2) based on hemorrhage, inflammatory cells, and epithelial sloughing (total six points) (5). Random sections $(\times 10 /$ slide $)$ of blinded Egr-1 slides were scored (0-2 for staining around the airways, connective tissue, and peripheral lung tissue). Cells positive for Egr-1 and $\mathrm{HO}-1$ were counted per low-power $(10 \times)$ field.

\section{Data Analysis and Statistics}

Results are shown as mean (SEM). Statistics were analyzed using InStat (GraphPad, La Jolla, CA) with Student's $t$-test and Mann-Whitney nonparametric tests as appropriate. Significance was accepted as $P<0.05$.

\section{STATEMENT OF FINANCIAL SUPPORT}

This work was supported by grant HD-12714 from the National Institute of Child Health and Development, National Institutes of Health, grant K08 HL097085 (to N.H.H.), and the Women and Infants Research Foundation.

\section{ACKNOWLEDGMENT}

We thank Megan McAuliffe for her assistance in the laboratory.

\section{REFERENCES}

1. Jobe AH, Hillman N, Polglase G, Kramer BW, Kallapur S, Pillow J. Injury and inflammation from resuscitation of the preterm infant. Neonatology 2008;94:190-6.

2. Kattwinkel J, Perlman JM, Aziz K, et al. Neonatal resuscitation: 2010 American Heart Association Guidelines for cardiopulmonary resuscitation and emergency cardiovascular care. Pediatrics 2010;126:e1400-13.

3. Fanaroff AA, Stoll BJ, Wright LL, et al. Trends in neonatal morbidity and mortality for very low birthweight infants. Am J Obstet Gynecol 2007;196:147.e1-8.

4. Pillow JJ, Hillman NH, Polglase GR, et al. Oxygen, temperature and humidity of inspired gases and their influences on airway and lung tissue in near-term lambs. Intensive Care Med 2009;35:2157-63.

5. Hillman NH, Kallapur SG, Pillow JJ, et al. Airway injury from initiating ventilation in preterm sheep. Pediatr Res 2010;67:60-5.

6. Schmölzer GM, Kamlin OC, O’Donnell CP, Dawson JA, Morley CJ, Davis PG. Assessment of tidal volume and gas leak during mask ventilation of preterm infants in the delivery room. Arch Dis Child Fetal Neonatal Ed 2010;95:F393-7.

7. Resende JG, Menezes CG, Paula AM, et al. Evaluation of peak inspiratory pressure and respiratory rate during ventilation of an infant lung model with a self-inflating bag. J Pediatr (Rio J) 2006;82:359-64.

8. Hillman NH, Moss TJ, Kallapur SG, et al. Brief, large tidal volume ventilation initiates lung injury and a systemic response in fetal sheep. Am J Respir Crit Care Med 2007;176:575-81.

9. Hillman NH, Nitsos I, Berry C, Pillow JJ, Kallapur SG, Jobe AH. Positive end-expiratory pressure and surfactant decrease lung injury during initiation of ventilation in fetal sheep. Am J Physiol Lung Cell Mol Physiol 2011;301:L712-20.

10. Hillman NH, Polglase GR, Pillow JJ, Saito M, Kallapur SG, Jobe AH. Inflammation and lung maturation from stretch injury in preterm fetal sheep. Am J Physiol Lung Cell Mol Physiol 2011;300:L232-41.

11. Wada K, Jobe AH, Ikegami M. Tidal volume effects on surfactant treatment responses with the initiation of ventilation in preterm lambs. J Appl Physiol 1997;83:1054-61.

12. Saugstad OD, Ramji S, Soll RF, Vento M. Resuscitation of newborn infants with $21 \%$ or $100 \%$ oxygen: an updated systematic review and meta-analysis. Neonatology 2008;94:176-82.
13. Dawson JA, Kamlin CO, Wong C, et al. Oxygen saturation and heart rate during delivery room resuscitation of infants $<30$ weeks' gestation with air or 100\% oxygen. Arch Dis Child Fetal Neonatal Ed 2009;94:F87-91.

14. Escrig R, Arruza L, Izquierdo I, et al. Achievement of targeted saturation values in extremely low gestational age neonates resuscitated with low or high oxygen concentrations: a prospective, randomized trial. Pediatrics 2008;121:875-81.

15. Vento M, Moro M, Escrig R, et al. Preterm resuscitation with low oxygen causes less oxidative stress, inflammation, and chronic lung disease. Pediatrics 2009;124:e439-49.

16. Chambellan A, Cruickshank PJ, McKenzie P, et al. Gene expression profile of human airway epithelium induced by hyperoxia in vivo. Am J Respir Cell Mol Biol 2006;35:424-35.

17. Brew N, Hooper SB, Allison BJ, Wallace MJ, Harding R. Injury and repair in the very immature lung following brief mechanical ventilation. Am J Physiol Lung Cell Mol Physiol 2011;301:L917-26.

18. Mulrooney N, Champion Z, Moss TJ, Nitsos I, Ikegami M, Jobe AH. Surfactant and physiologic responses of preterm lambs to continuous positive airway pressure. Am J Respir Crit Care Med 2005;171:1-6.

19. Copland IB, Martinez F, Kavanagh BP, et al. High tidal volume ventilation causes different inflammatory responses in newborn versus adult lung. Am J Respir Crit Care Med 2004;169:739-48.

20. Kroon AA, Wang J, Huang Z, Cao L, Kuliszewski M, Post M. Inflammatory response to oxygen and endotoxin in newborn rat lung ventilated with low tidal volume. Pediatr Res 2010;68:63-9.

21. Hillman NH, Kallapur SG, Pillow JJ, et al. Inhibitors of inflammation and endogenous surfactant pool size as modulators of lung injury with initiation of ventilation in preterm sheep. Respir Res 2010;11:1-8.

22. Hillman NH, Pillow JJ, Ball MK, Polglase GR, Kallapur SG, Jobe AH. Antenatal and postnatal corticosteroid and resuscitation induced lung injury in preterm sheep. Respir Res 2009;10:124.

23. Copland IB, Post M. Stretch-activated signaling pathways responsible for early response gene expression in fetal lung epithelial cells. J Cell Physiol 2007;210:133-43.

24. Silverman ES, Collins T. Pathways of Egr-1-mediated gene transcription in vascular biology. Am J Pathol 1999;154:665-70.

25. Hoetzel A, Dolinay T, Vallbracht S, et al. Carbon monoxide protects against ventilator-induced lung injury via PPAR-gamma and inhibition of Egr-1. Am J Respir Crit Care Med 2008;177:1223-32.

26. Jones N, Agani FH. Hyperoxia induces Egr-1 expression through activation of extracellular signal-regulated kinase $1 / 2$ pathway. J Cell Physiol 2003;196:326-33.

27. Choi AM, Alam J. Heme oxygenase-1: function, regulation, and implication of a novel stress-inducible protein in oxidant-induced lung injury. Am J Respir Cell Mol Biol 1996;15:9-19.

28. Frank L, Sosenko IR. Prenatal development of lung antioxidant enzymes in four species. J Pediatr 1987;110:106-10.

29. Cheah FC, Jobe AH, Moss TJ, Newnham JP, Kallapur SG. Oxidative stress in fetal lambs exposed to intra-amniotic endotoxin in a chorioamnionitis model. Pediatr Res 2008;63:274-9.

30. Kramer BW, Jobe AH, Ikegami M. Monocyte function in preterm, term, and adult sheep. Pediatr Res 2003;54:52-7.

31. Gitto E, Pellegrino S, D'Arrigo S, Barberi I, Reiter RJ. Oxidative stress in resuscitation and in ventilation of newborns. Eur Respir J 2009;34: $1461-9$.

32. Solberg R, Løberg EM, Andresen JH, et al. Resuscitation of newborn piglets. short-term influence of $\mathrm{FiO}_{2}$ on matrix metalloproteinases, caspase-3 and BDNF. PLoS ONE 2010;5:e14261.

33. Kumar VH, Patel A, Swartz DD, et al. Exposure to supplemental oxygen and its effects on oxidative stress and antioxidant enzyme activity in term newborn lambs. Pediatr Res 2010;67:66-71.

34. Yu AY, Frid MG, Shimoda LA, Wiener CM, Stenmark K, Semenza GL. Temporal, spatial, and oxygen-regulated expression of hypoxia-inducible factor-1 in the lung. Am J Physiol 1998;275(4 Pt 1):L818-26.

35. Asikainen TM, Ahmad A, Schneider BK, White CW. Effect of preterm birth on hypoxia-inducible factors and vascular endothelial growth factor in primate lungs. Pediatr Pulmonol 2005;40:538-46. 
36. Grover TR, Asikainen TM, Kinsella JP, Abman SH, White CW. Hypoxiainducible factors HIF-1alpha and HIF-2alpha are decreased in an experimental model of severe respiratory distress syndrome in preterm lambs. Am J Physiol Lung Cell Mol Physiol 2007;292:L1345-51.

37. Ali NK, Jafri A, Sopi RB, Prakash YS, Martin RJ, Zaidi SI. Role of arginase in impairing relaxation of lung parenchyma of hyperoxia-exposed neonatal rats. Neonatology 2012;101:106-15.
38. Jobe AH, Kramer BW, Moss TJ, Newnham JP, Ikegami M. Decreased indicators of lung injury with continuous positive expiratory pressure in preterm lambs. Pediatr Res 2002;52:387-92.

39. Lowry OH, Rosebrough NJ, Farr AL, Randall RJ. Protein measurement with the Folin phenol reagent. J Biol Chem 1951;193:265-75.

40. KramerBW,Moss TJ,WilletKE,etal.Doseandtimeresponseafterintraamniotic endotoxin in preterm lambs. Am J Respir Crit Care Med 2001;164:982-8. 